\title{
Wyśpiewać wartości. Wychowanie chrześcijańskie na lekcjach języka angielskiego w katolickiej szkole podstawowej w Belfaście
}

\section{Sing Away the Values: Christian Education in English Lessons in a Catholic Primary School}

\begin{abstract}
ABSTRAKT
Wychowanie chrześcijańskie w szkole to nie tylko lekcje religii. Niniejszy artykuł podejmuje kwestię wychowania chrześcijańskiego z wykorzystaniem wartościowego repertuaru muzycznego w edukacji wczesnoszkolnej na przykładzie doświadczeń ze szkoły podstawowej w Belfaście. Na wczesnym etapie edukacji, kiedy mamy do czynienia z kształceniem zintegrowanym, można w łatwy sposób nawiq̨zywać do wartości chrześcijańskich podczas codziennych zajęć szkolnych. Czy można jednak połaczyć wychowanie chrześcijańskie z nauczaniem języka angielskiego?

W artykule zostanq zaprezentowane opracowania dotyczqce nauki ięzyka, a wykorzystujące utwory muzyczne, które odwołuja się do wartości duchowych w rozumieniu Maxa Schelera. Nawiqzując do założeń fińskiej edukacji muzycznej oraz edukacji religijnej, zostanq
\end{abstract}

SLOWA KLUCZOWE wychowanie chrześcijańskie, nauczanie języka angielskiego, wspólne śpiewanie, nauczanie muzyki, edukacja religijna

\section{KEYWORDS}

Christian education, teaching English, singing, teaching music, religious education

SPI Vol. 23, 2020/1 ISSN 2450-5358 e-ISSN 2450-5366 DOI: 10.12775/SPI.2020.1.005 
przedstawione wartości płynq̨ce z opisanego rozwiqzania. Zaprezentowane przykłady będq omówione z wykorzystaniem odwołań do literatury, która zarysowuje szerszy obraz wychowania chrześcijańskiego we wczesnej edukacji dziecka. Pomocne będzie również odwołanie się do następujących kategorii: pedagogika katolicka, edukacja religijna, wychowanie chrześcijańskie, wartości duchowe czy też eurytmia, kłóre leżq u podstaw teoretycznych tego artykułu.

\section{ABSTRACT}

Christian education at school is carried out not only during religion lessons. This article deals with the issue of Christian education using the valuable musical repertoire in early school education on the example of experience gained from an elementary school in Belfast. At an early stage of education, when students have an integrated education, it is easy to refer to Christian values during everyday school activities. Is it possible to combine Christian education with teaching English lessons?

The article will present studies on language learning, and using musical works that refer to spiritual values as they are understood by Max Scheler. Referring to the assumptions of Finnish music education and religious education, the values resulting from the described solution will be presented. The examples presented will be discussed using references to literature that outlines the broader shape of Christian education in early childhood education. It will also be helpful to refer to the following categories: Catholic pedagogy, religious education, Christian education, spiritual values or eurhythmics, which are the theoretical foundations of this article.

\section{Wstęp}

Tytuł artykułu, który nawiązuje do czynności śpiewania, nie został przeze mnie wybrany przypadkowo. Jako nauczyciel edukacji wczesnoszkolnej wiem, że wyśpiewać można nie tylko wartości nut, ale również tabliczkę mnożenia, alfabet czy przepis na ciasto. $\mathrm{Mu}-$ zyka jest obecna w życiu człowieka od początku jego istnienia i od zawsze pełniła ważną rolę we wszechstronnym wychowaniu dziecka. W dzisiejszym nauczaniu początkowym, pomimo nieznacznej obecności edukacji muzycznej, nie powinniśmy zapominać o jej zbawiennym wpływie na rozwój dziecka. Wczesne umuzykalnianie pomaga 
rozwinąć pozytywne cechy charakteru (optymizm, humor, radość) oraz rozbudzić wrażliwość na przeżycia estetyczne. Faktem jest, że muzyka aktywizuje nasz mózg i pomaga w przyswajaniu zasad ortografii, gramatyki, matematyki i wychowania fizycznego (Kisiel 2007: 35). Dzięki wychowaniu muzycznemu szybciej uczymy się czytać, mamy lepszą pamięć, wymowę oraz myślimy bardziej logicznie. Dowiedziono również, że w grupie czy w klasie szkolnej dzieci porozumiewają się szybciej i sprawniej (Kisiel 2007: 69). Ale czy można śpiewać o wartościach ważnych w wychowaniu chrześcijańskim? Jakie piosenki mogą być odpowiednie dla dzieci w wieku wczesnoszkolnym? W jaki sposób rozmawiać o tym, co już zostało wyśpiewane z dziecięcą radością? Działania te wpisują się w założenia pedagogiki chrześcijańskiej, która ze względu na swój empiryczny charakter zajmuje się głównie „badaniem praktycznych form realizowania wychowania chrześcijańskiego $\mathrm{w}$ różnych nieformalnych i formalnych środowiskach przez różne osoby podejmujące niezinstytucjonalizowane i zinstytucjonalizowane działania wychowawcze (Olbrycht 2013: 124).

$\mathrm{W}$ artykule zostanie poruszony aspekt formalnego środowiska - szkoły podstawowej, w której dominują wychowawcze działania zinstytucjonalizowane. Pedagogika chrześcijańska ma również za zadanie sprawdzać, czy proponowane przez nauczycieli działania sprawdzają się metodycznie i organizacyjnie w kwestii wychowania chrześcijańskiego. Jej źródłem jest bowiem doktryna chrześcijańska, dokumenty Kościoła oraz antropologia i aksjologia, które odwołują się do religii chrześcijańskiej. Specyfikę natomiast najlepiej określa pedagogika normatywna, u podstaw której należy się doszukiwać chrześcijańskiej koncepcji człowieka, wartości i kultury. To ona określa cele i zasady działań zorientowanych na wszechstronne wychowanie chrześcijańskie. Warto również dodać, że w ramach pedagogiki chrześcijańskiej wypracowuje się pedagogiki poszczególnych wyznań chrześcijańskich, z których najbardziej rozwiniętą jest pedagogika katolicka. W tym tekście chciałbym nawiązać do praktyki edukacyjnej, jaka miała miejsce w katolickiej szkole podstawowej w Belfaście. W 2016 roku jako nauczyciel-praktykant miałem okazję obserwować oraz prowadzić zajęcia muzyczne w jednej z lokalnych szkół podstawowych w Irlandii Północnej. Doświadczenia te stały się główną motywacją do napisania tego artykułu, który ma ukazać nietypowe podejście do muzycznego wychowania chrześcijańskiego. 


\section{Założenia edukacji religijnej i sens wychowania chrześcijańskiego}

Oprócz wszechstronnej edukacji elementarnej, istnieje również bardzo ważna w życiu młodego człowieka edukacja religijna. W literaturze znajdziemy liczne przykłady związków edukacji i religii, gdyż to właśnie wymiar religijny jest "głównym czynnikiem motywującym człowieka do wysiłku budowania siebie" (Nowak 2012: 324). Warto podkreślić za Katarzyną Olbrycht (2013), że celem tejże edukacji jest przekazanie wiedzy o religii jako zjawisku kulturowym, wiedzy o własnej i innych religiach, szczególnie tych, które są obecne lokalnie. Edukacja religijna jest to jednak jedynie jeden $\mathrm{z}$ trzech obszarów wychowania religijnego. Oprócz niej to również wychowanie do religijności oraz wychowanie do i w określonej religii (Olbrycht 2013: 126). Istotne jest, aby pamiętać, że edukacja religijna na etapie wczesnoszkolnym powinna służyć pogłębianiu wiedzy dzieci o własnej religii, kształtowaniu szacunku do drugiego człowieka i jego wyznania oraz kultury. Opisane przez Katarzynę Olbrycht wychowanie do religijności jest dla mnie esencją działań, które dokładnie opiszę w dalszej części artykułu. Jest to bowiem wychowanie do wrażliwego odczytywania, rozumienia i szanowania religijności każdego człowieka, ale równocześnie wychowanie kształcące potrzebę poszukiwania prawdy, dobra i piękna, otwierania się na transcendencję, kontemplowania świata, poszukiwania jego sensu, do podziwu i zachwytu nad światem, co ma prowadzić do odkrywania w nim objawiającego się Boga. Kształcenie religijności wiąże się $\mathrm{z}$ budowaniem własnego człowieczeństwa (Olbrycht 2013: 128).

U podstaw tych wszystkich działań powinno być wychowanie w wierze chrześcijańskiej, która oparta na miłości Chrystusa przekłada się postawę człowieka rozumiejącego potrzebę wychowania do wartości osobowych. Wychowanie chrześcijańskie, do którego nawiązuję, można postrzegać zarówno w wymiarze antropologicznym, jak i personalistycznym (Cichosz 1997: 177). Ten pierwszy, oparty na tradycji filozofii arystotelesowsko-tomistycznej, ukazuje wychowanie jako naturalny rozwój człowieka, który, będąc kierowany przez wychowawców, jest ciągłym procesem prowadzącym poprzez szereg działań do osiągnięcia wszechstronnego rozwoju. Według Cichosza istotą $\mathrm{w}$ tym podejściu jest podkreślanie, że wychowanie 
polega na wyzwalaniu potencjalności rozwojowych człowieka oraz umacnianiu go w czynieniu dobra (Cichosz 1997: 180). Kontekst personalistyczny natomiast oznacza, że „centralnym momentem procesu wychowawczego powinien być człowiek jako osoba" (Cichosz 1997: 180). Oczywiście perspektywa ta powiązana jest z filozofią egzystencjalizmu i ostateczną chrześcijańską interpretacją. W literaturze często podkreśla się, że każdy człowiek znajduje się na drodze do stawania się osobą, którą cechuje otwarcie na dobro, prawdę i piękno i wybory związane $\mathrm{z}$ hierarchią wartości nakierowaną na wartości duchowe i absolutne. Te ostatnie rozumiane są w wychowaniu chrześcijańskim jako miłość Boża (Gadacz 1993: 108-109). Niemniej jednak we wszystkich koncepcjach wychowania chrześcijańskiego akcentuje się mocno znaczenie relacji opartej na dialogu między wychowawcą, który jest osobowym autorytetem, a wychowankiem, który rozwija się poprzez przyswajanie wartości relacji społecznych (Buber 1968: 460). Według Cichosza (1997) możemy nawet wyróżnić dwa poziomy wychowania chrześcijańskiego, które obrazuje poniższa tabela.

Tabela 1. Dwa poziomy wychowania religijnego

\begin{tabular}{|l|l|}
\hline Poziom wychowania & \multicolumn{1}{|c|}{ Charakterystyka } \\
\hline Naturalny & $\begin{array}{l}\text { Zwiqzany z egzystencjalnym widzeniem człowieka. Zadaniem i celem tego } \\
\text { wychowania jest prawidłowy rozwój człowieka z uwzględnieniem jego wro- } \\
\text { dzonych możliwości (fizycznych, umysłowych i duchowych). Jest to uniwersalny } \\
\text { poziom wychowania, w którym podkreśla się nienaruszalne prawo do wycho- } \\
\text { wania według własnych dostosowań, ale nastawiony na braterskie współżycie, } \\
\text { jedność i pokój na ziemi. }\end{array}$ \\
\hline Religijny & $\begin{array}{l}\text { Prawo do wychowania religijnego dla osób ochrzczonych i wierzqcych, dla } \\
\text { których celem ostatecznym jest pojednanie i zjednoczenie z Bogiem. Wymiar } \\
\text { postaw moralnych dotyczy osiqgnięcia cnót teologicznych (wiara, nadzieja, } \\
\text { miłość) poprzez kontakt z Bogiem w procesie wewnętrznei przemiany. }\end{array}$ \\
\hline
\end{tabular}

Źródło: Opracowanie własne na podstawie: Cichosz (1997: 183).

Wzajemne uzupełnianie się tych poziomów prowadzi do pełnego rozwoju osoby ludzkiej, która dzięki poznawanej stopniowo nauce Chrystusa staje się doskonalsza każdego dnia. 


\section{Wartości chrześcijańskie w edukacii wczesnoszkolnej}

Problematyka wartości była poruszana już w starożytnej myśli filozoficznej. Już Platon rozwinął filozoficzne rozumienie pojęcia idei, której znajomość jest warunkiem właściwego wartościowania otaczających nas rzeczy. Na tej podstawie wyróżnił trzy wartości: prawdę, piękno i dobro, które zostały uznane przez niego za najważniejsze. Marian Nowak pisze:

Wartości wyrażają to, co być powinno i czego pragniemy, wpisują w rzeczywistość pewien sens ostateczny, ukazują to, co naprawdę istotne i do czego warto dążyć. Są filarami, na których opiera się życie społeczne, osobiste i wspólnotowe. Podstawowe zachowania ludzkie są przez nie motywowane i regulowane (Nowak 2001: 393).

Niemiecki filozof Max Scheler mówił o pięciu grupach wartości, do których postanowiłem się odnieść w kontekście podejmowanych przeze mnie działań w edukacji wczesnoszkolnej. Owe pięć grup podzielił następująco: wartości absolutne (najważniejsze), wartości duchowe (kulturowe), wartości witalne, wartości utylitarne, wartości hedonistyczne (Wołosiuk 2011: 186). Chciałbym poświęcić uwagę wartościom duchowym (kulturowym), które zostały podzielone na następujące części: wartości estetyczne, wartości poznania prawdy, wartości moralne (dobro). Do tej właśnie grupy odnosiłem się najczęściej podczas rozmów podejmowanych z dziećmi o śpiewanych wspólnie piosenkach. Trudno jednak wymienić wszystkie wartości chrześcijańskie, gdyż według Mariana Nowaka są to w zasadzie wszystkie wartości ogólnoludzkie wzbogacone o głębię i sens, które nadaje sam Bóg, oraz odnoszą się do godności i praw osoby ludzkiej.

Wartości w pedagogice traktowane są zatem jako drogowskazy, wskazówki lub ukazywane są po prostu w ludzkich postawach. $\mathrm{Na}$ etapie wczesnej edukacji to właśnie ten ostatni sposób ich traktowania jest dla dzieci najbardziej obrazowy. Na konkretnym przykładzie zachowania dziecka lub dorosłego mogą one zrozumieć istotę danej wartości i odnieść ją do własnego postępowania. Ciekawe są też proponowane przez Nowaka (2001: 423-424) tzw. strategie przekazywania wartości, które można wykorzystać podczas rozmów z podopiecznymi. Przede wszystkim jest to strategia dysonansu, która polega na skonfrontowaniu ucznia z odmiennymi sposobami myślenia i oceniania. Druga z nich to strategia świadectwa, której celem 
jest pobudzenie i wyzwolenie w uczniach mechanizmu identyfikacji, tzw. nieświadome przejęcie pewnych cech drugiej osoby. Ostatnią jest strategia symulacji, w której zadaniem nauczyciela jest ukonkretnienie wartości, na które wychowanek może być już wrażliwy. Wymienione wyżej metody mogą mieć zastosowanie w kontekście wspomnianych wartości duchowych, które chcemy podkreślać w codziennej edukacji.

\section{Edukacja muzyczna}

Prowadzone przeze mnie w szkole zajęcia muzyczne w języku angielskim odbywały się jeden raz w tygodniu, w każdy czwartek. W każdym tygodniu uczniowie osłuchiwali się z jedną nową piosenką oraz powtarzali znany już utwór z poprzedniego tygodnia. Moim celem było, by każdy z uczniów opanował płynnie dwie piosenki w ciągu miesiąca. Na każdych zajęciach, oprócz słuchania i śpiewania, wykorzystywaliśmy utwór do rozmowy o samopoczuciu i wspólnie dokonywaliśmy jego interpretacji. Piosenki te zazwyczaj zawierały krótkie, często powtarzające się frazy, których dzieci w sposób szybki i łatwy mogły się nauczyć. W większości przypadków układaliśmy także prosty układ choreograficzny, by śpiewanie stało się jeszcze przyjemniejsze. W innym artykule odniosłem się do celów edukacji muzycznej, którą miałem okazję obserwować w fińskiej szkole podstawowej. Przypomnę jedynie, że wiele $z$ nich jest realizowanych przez irlandzkich nauczycieli. Myślę, że cele te powinny przyświecać również polskim nauczycielom, którzy mogliby wspomagać dydaktykę nauczanego przedmiotu zajęciami muzycznymi. W fińskiej podstawie programowej znajdziemy następujące cele: interpretowanie wieloznaczności muzyki w różnych kulturach i w działaniach jednostki oraz społeczności lokalnej; wzmacnianie pozytywnego doświadczania muzyki oraz położenie fundamentu pod zainteresowanie muzyką, co może trwać całe życie; rozwijanie krytycznego myślenia dotyczącego odbioru muzycznego oraz dbanie o rozwój wyrażania ekspresyjności uczniów (Adamczewski 2018: 259). Ponadto nasi uczniowie powinni być świadomi, dlaczego uczymy ich takiego właśnie utworu i kto jest jego twórcą. Na etapie początkowym, czyli w trakcie pierwszego słuchania utworu, zadaniem nauczyciela jest upewnienie się, czy uczniowie dobrze zrozumieli śpiewany/słuchany tekst piosenki, zobaczyli jego formę pisaną oraz 
poprawnie wymawiają słowa piosenki indywidualnie oraz grupowo. Ważne będzie również zwrócenie uwagi na samodzielne zaczynanie i kończenie utworu z i bez pomocy nauczyciela. Kolejnym etapem, który ma miejsce na następnych zajęciach z daną piosenką, jest przygotowanie do świadomego śpiewania. W tym czasie uczniowie znają już tekst, w większości potrafią go już poprawnie artykułować oraz znają tytuł i autora. W tej części często korzystam z metodyki Rudolpha Steinera, który wprowadzając eurytmię do szkoły waldorfskiej chciał, aby spełniała ona rolę pośrednika między słowem a ruchem. Według Jadwigi Wasiukiewicz, eurytmia to nic innego jak uwidocznienie mowy i dźwięku poprzez piękny ruch i kolor.

Połączenie [...] polega na harmonii przeżyć, działania i zachowania. Transponuje ono mowę żywego słowa na mowę rytmu i gestu. Podczas śpiewu doświadczamy również wewnętrznych przeżyć, które możemy przedstawić za pomocą widzialnych form ruchu. Zadaniem tego przedmiotu, oprócz ćwiczeń usprawniających płynność i delikatność ruchu, jest możliwość poznania własnego ciała, lepsze i pełniejsze wypowiadanie się przez ruch, gest, mimikę, doskonalenie orientacji przestrzennejsłowem „uduchowienia kultury fizycznej”. Później służy ona do wyrażania treści utworów i pieśni - jest „widzialnym językiem” i „widzialnym śpiewem” i pełni funkcję uszlachetniającą i integrującą (Wasiukiewicz 1998: 30-31).

Zadaniem nauczyciela jest zatem zwrócenie uwagi uczniów na znaczenie tekstu, jego przesłania, i sprawdzenie jego zrozumienia przez uczniów. Na przykład, czy wszyscy dostrzegamy radość lub smutek w tej piosence? Czy wszyscy rozumiemy dlaczego właśnie w tej piosence dziękujemy Bogu, a nie św. Mikołajowi? Będzie to nam potrzebne, by w dalszej części śpiewania i wyrażania ruchem naszych utworów uczniowie mogli pomyśleć o przekazywanych przez utwór wartościach chrześcijańskich i spróbowali odnieść je do przykładów z własnego życia. Poniżej przedstawię kilka utworów, które wspólnie wyśpiewaliśmy w ciągu mojej praktyki pedagogicznej w Belfaście. Nawiążę również do dziecięcej interpretacji, która wielokrotnie pokazała dojrzałość poznawczą dzieci na tym etapie rozwojowym.

Wybierany przeze mnie lub przez dzieci repertuar muzyczny nie jest nigdy przypadkowy. Piosenka powinna bowiem odzwierciedlać możliwości wokalne dzieci oraz nawiązywać do ich zainteresowań. Również ważne jest, by utwór był skoczny, radosny i zróżnicowany muzycznie. Wielość instrumentów, klaskanie i zmiany tempa działają 
na dzieci motywująco. Większość piosenek została stworzona przez osoby wierzące lub zajmujące się edukacją religijną dzieci w krajach anglojęzycznych. Poszukujący nauczyciel znajdzie ich setki na popularnym internetowym serwisie muzycznym. Rolą nauczyciela jest jednak dokonanie wyboru (czasem wraz z dziećmi) i wcześniejsze samodzielne przygotowanie go do odtworzenia i zaśpiewania lub odegrania na instrumencie muzycznym.

\section{Wartościowe piosenki na lekcjach angielskiego}

W tej części artykułu przedstawię piosenki, które będą nawiązywać do trzech wymienionych wcześniej wartości duchowych: wartości estetyczne, wartości poznania prawdy oraz wartości moralne (poznanie dobra). Oprócz zaproponowanej powyżej klasyfikacji wartości Schelera, warto przytoczyć definicję wartości duchowych opracowaną przez Józefa Tischnera, który umiejscawia je jako przedostatnie w swojej klasyfikacji:

[...] wartości, wśród których łatwo rozpoznać Platońską triadę: Prawdę, Dobro i Piękno. W tej triadzie Prawda jest wartością przewodnią, ponieważ umożliwia rozpoznanie sytuacji i działania etyczne (Tischner 1982: 68-77).

W literaturze znajdziemy także opis Natalii Zhyhaylo, która określa wartości duchowe jako wcielenie w orientację światopoglądową człowieka wiary, pragnień, ideałów, ducha narodu, nacji, co wyznacza kierunek osobistych potrzeb, pragnień i warunkuje jego kierunek życia. To uzmysłowienie sobie przez człowieka humanistycznej szansy, celu jego ludzkiej działalności (por. Zhyhaylo 2016: 293).

Rozpocznę od przedstawienia piosenki związanej z odczuwaniem przez uczniów wartości estetycznych. Piosenka stworzona przez Raffiego Cavoukiana, kanadyjskiego autora piosenek dla dzieci. Jego muzyka została doceniona na całym świecie, a 13 albumów poświęconych dzieciom pomimo upływu lat nie straciło na wartości. Jednym $z$ utworów jest Thanks a lot (1980), który opowiada o wspaniałym, otaczającym nas świecie. Ze względu na liryczny charakter piosenki, dzieci chętnie śpiewają ją w pozycji leżącej, z zamkniętymi oczami, wyobrażając sobie wszystko, co zostało stworzone przez Boga. W przetłumaczonym fragmencie możemy zobaczyć jak 
autor piosenki starał się wzbudzić w dzieciach poczucie estetyki oraz wdzięczności wobec otaczającej je rzeczywistości.

Thanks a lot, thanks for Sun in the sky. Thanks a lot, thanks for whispering wind. Thanks a lot, thanks for the birds in the spring. Thanks for the animals, for the land, for the people everywhere. Thanks for all I've got.

Dziękuję bardzo, dziękuję za słońce na niebie. Dziękuję bardzo, dziękuję za szepczący wiatr. Dziękuję bardzo, dziękuję za ptaki przylatujące wiosną. Dziękuję za zwierzęta, za ziemię i ludzi dookoła niej. Dziękuję za wszystko, co mam.

W piosence nie pojawia się imię stwórcy wszystkich pięknych rzeczy, ale sama treść zachęca dzieci do zadawania pytań o stworzenie świata. Wraz z dziećmi rozmawiamy wtedy o rzeczach i osobach, bez których nie wyobrażamy sobie życia. Ciekawym pomysłem jest również śpiewanie tej piosenki na koniec każdego tygodnia, zanim uczniowie rozejdą się do domów. Dziękujemy wtedy za cały tydzień, który wspólnie przeżyliśmy i za rzeczy, o których się dowiedzieliśmy lub które mieliśmy okazję zobaczyć.

\section{Wartości poznania prawdy}

Piosenka Honestly be Honest (2015) stworzona przez organizację chrześcijańską INCKids, oprócz nawoływania do mówienia prawdy, zachęca również dzieci do muzykowania. Melodia jest na tyle prosta, że uczniowie podczas jej śpiewania chętnie akompaniują na własnych instrumentach. Utwór opowiada o radości, jaką czuje Bóg i człowiek, kiedy mówimy prawdę. Podkreśla również w prostych słowach, że mówienie prawdy jest ważne i każdy zasługuje, by ją znać.

You might think that no one else will know, but the Lord our God will always know. Honestly, be Honest and you'll see, when you tell the truth, how happy God will be. In everything, do your best to be True, and God will be so very pleased with you!

Możesz myśleć, że nikt inny nie dowie się, ale Bóg zawsze będzie wiedział. Szczerze, bądź szczery, a zobaczysz, jak Bóg będzie szczęśliwy, kiedy powiesz prawdę. We wszystkim, co robisz, zawsze prawdę mów, a Bóg będzie z ciebie dumny! 
W trakcie śpiewania tej piosenki staram się przekręcać słowa, które dzieci już znają, by dowiedzieć się od nich, dlaczego ważne jest mówienie prawdy, choćby w kontekście przekręcania słów. Rozmawiamy także o wielkości prawdy i o tym, czy zawsze prawda jest przyjemna i miła. Powtarzamy ją również wspólnie, kiedy w klasie pojawi się kłamstwo i przypominamy sobie, dlaczego warto mówić prawdę. Pamiętam dobrze, że dzieci opowiadały o sytuacjach, w których zostały okłamane. Mówiąc otwarcie o swoich uczuciach, nazywaliśmy je i próbowaliśmy śpiewać razem piosenkę wykorzystując te uczucia.

\section{Wartości moralne}

W tym przypadku z pomocą przychodzi nam chrześcijańska grupa muzyczna Listener Kids, która w swoim albumie Let It Shine (2016) zaprezentowała znaną już piosenkę nieznanego autora pt. I've got peace like a river w zupełnie nowej aranżacji. Dzieci uwielbiały tę piosenkę ze względu na jej rytm oraz prostą i wesołą linię melodyczną. Utwór opowiada o takich wartościach jak pokój, miłość i radość, optymizm, których ilość jest porównana do natury.

I've got peace like a river in my soul. I've got love like an ocean in my soul. I've got joy like a fountain in my soul. I've got peace, love and joy like a river.

Boży pokój jak rzeka wypełnia duszę mą. Boża miłość jak ocean wypełnia duszę mą. Boża radość jak fontanna wypełnia duszę moją. Boży pokój, miłość i radość wypełnia duszę mą.

Piosenka ta znana jest również w języku polskim pod tytułem Boża radość. Od kiedy pamiętam, cieszyła się ona dużą popularnością wśród dzieci. Przy okazji wspólnego śpiewania i „pokazywania” piosenki rozmawialiśmy o wartościach, które są ważne dla nas, by każdy czuł się dobrze na świecie. Dzieci chętnie opowiadały, że świat bez radości, pokoju i miłości byłby miejscem strasznym i niebezpiecznym. Warto wtedy podkreślić, że właśnie te wartości mają początek w każdym z nas. Kiedy będziemy pełni pokoju, radości i miłości wtedy będziemy w taki sposób widzieć świat wokół nas. 


\section{Podsumowanie}

Ciekawych piosenek dla dzieci, które opowiadają o ważnych dla nich wartościach, można znaleźć setki w internecie. Najważniejsze jest jednak, by tworzyć sytuacje sprzyjające rozwijaniu umiejętności komunikacyjnych naszych uczniów. Słuchanie i wspólne wykonywanie utworów zawierających w sobie wartości chrześcijańskie przyczynia się nie tylko do „zanurzenia dziecka w języku”, ale przede wszystkim wspiera samodzielność w analizowaniu tekstu. Według Barbary Murawskiej „wspieranie zdolności do rozumienia tekstów wymaga ze strony nauczyciela stopniowego wypracowania w uczniach niezależności w działaniu zmierzającym do rozumienia tekstu, obudzenia ich zainteresowania tekstem, a ze strony uczniów polega na stopniowym przejmowaniu inicjatywy w budowaniu rozumienia" (Murawska 2014: 39). Raz jeszcze zatem podkreślę wagę nauczyciela, który oprócz nauczania matematyki, języka angielskiego czy też muzyki, może chętnie poruszać z uczniami rozmowy o ludzkich postawach, które są potrzebne światu. Może to właśnie dzięki nim nasi podopieczni odkryją, że uosobieniem tych wszystkich wartości jest Bóg, który w Jezusie może być dla nas przykładem do naśladowania. Nie możemy jednak zapominać, że wpływ na edukację religijną naszych wychowanków ma przede wszystkim dom rodzinny, który jest właściwym i pierwszym miejscem wychowania. Szkoła powinna jednak pełnić funkcję wyrównawczą i uzupełniać zauważone braki wynikające ze środowiska rodzinnego.

Celem tego artykułu było również zwrócenie uwagi na to, że urzeczywistnianie wartości, które mamy wpajać naszym uczniów, może się dokonywać również za pomocą wspólnego śpiewania. Mam nadzieję, że zaobserwowane przeze mnie w Belfaście działania staną się motywacją dla innych nauczycieli, by wykorzystywać każdą okazję do odważnych rozmów z naszymi uczniami o postawach, które są godne naśladowania. Teksty piosenek zaprezentowane w artykule sprawiły, że uczniowie nie tylko rozpoczęli własne muzykowanie, ale przede wszystkim zrozumieli tekst pisany, o którym zapragnęli później rozmawiać. Jest to zatem sukces nie tylko z perspektywy edukacji muzycznej, ale również edukacji językowej podejmowanej na wczesnym etapie. Wyśpiewajmy zatem wartości, wyśpiewajmy lepszy świat, w którym nie braknie wartości duchowych. 


\section{Bibliografia}

Adamczewski J. (2018). Edukacja muzyczna w klasach I-III. Dobre praktyki edukacyjne w finskich szkotach podstawowych, [w:] A. Gromkowska-Melosik, E. Grzesiak, J. Drozdowicz, M. Gierczyk (red.), Edukacja i spoteczeństwo. Dynamika socjopedagogicznych konstrukcji, Poznań: Wydawnictwo Naukowe UAM, s. 257-268.

Buber M. (1968). Wychowanie, przeł. S. Grygiel, „Znak”, nr 4(166), s. 442-461.

Cichosz M. (1997). Wychowanie chrześcijańskie - perspektywa teoretyczna i praktyczna koncepcji, [w:] T. Kukołowicz, M. Nowak (red.), Pedagogika ogólna. Problemy aksjologiczne, Lublin: Redakcja Wydawnictw KUL, s. 177-185.

Gadacz T. (1993). Wychowanie do wolności, [w:] F. Adamski (red.), Poza kryzysem tożsamości. W kierunku pedagogiki personalistycznej, Kraków: Instytut Pedagogiki UJ, Wydawnictwo Naukowe PAT, s. 97-108.

Kisiel M. (2007). Pedagogiczno-dydaktyczne aspekty wykorzystania muzyki w stymulacji rozwoju dziecka, Dąbrowa Górnicza: Wyższa Szkoła Biznesu.

Murawska B. (2014). Niezbęenik Dobrego Nauczyciela. Seria III. Edukacja wczesnoszkolna, t. 3, Warszawa: Instytut Badań Edukacyjnych.

Nowak M. (2001). Podstawy pedagogiki otwartej. Ujęcie dynamiczne w inspiracji chrześcijańskiej, Lublin: Redakcja Wydawnictw KUL.

Nowak M. (2012). Pedagogiczny profil nauk o wychowaniu. Studium zodniesieniami do pedagogiki pielegniarstwa, Lublin: Wydawnictwo KUL.

Olbrycht K. (2013). Wspótczesne obszary pedagogiki chrześcijańskiej. „Paedagogia Christiana”, nr 1(31), s. 121-135.

Tischner J. (1982). Etyka wartości i nadziei, [w:] D. von Hildebrand, J.A. Kłoczowski, J. Paściak, J. Tischner, Wobec wartości, Poznań: W Drodze, s. 51-148.

Wasiukiewicz J. (1998). Pedagogika waldorfska w praktyce, Gdańsk: Wydawnictwo UG.

Wołosiuk B. (2011). Wartości chrześcijanskie w wychowaniu dzieci w mtodszym wieku szkolnym, „Paedagogia Christiana”, nr 1(27), s. 185-202.

Zhyhaylo N. (2016). Ksztattowanie wartości duchowych mtodzieży studenckiej w kontekście wspótpracy transgranicznej, http://docplayer.pl/7104927-W-kontekscie-wspolpracy-transgranicznej.html [dostęp: 27.12.2019].

\section{ADRES DO KORESPONDENCJI}

Mgr Jakub Adamczewski

Uniwersytet im. Adama Mickiewicza w Poznaniu

Wydział Studiów Edukacyinych

e-mail: jakub.adamczewski@amu.edu.pl 